\title{
Induction of Mast-Cell Accumulation by Promutoxin, an Arg-49 Phospholipase $A_{2}$
}

\author{
Ji-Fu Wei, ${ }^{1,2,3}$ Xiao-Long Wei, ${ }^{2}$ Ya-Zhen Mo, ${ }^{2}$ Haiwei Yang, ${ }^{1}$ and Shaoheng He ${ }^{1,2}$ \\ ${ }^{1}$ Clinical Experiment Center, The First Affiliated Hospital of Nanjing Medical University, Nanjing 210029, China \\ ${ }^{2}$ Allergy and Inflammation Research Institute, The Shantou University Medical College, Shantou, Guangdong 515041, China \\ ${ }^{3}$ Research Division of Clinical Pharmacology, The First Affiliated Hospital of Nanjing Medical University, Nanjing 210029, China
}

Correspondence should be addressed to Shaoheng He; shoahenghe@hotmail.com

Received 23 July 2012; Accepted 11 September 2012

Academic Editor: Luis A. Ponce Soto

Copyright (C) 2013 Ji-Fu Wei et al. This is an open access article distributed under the Creative Commons Attribution License, which permits unrestricted use, distribution, and reproduction in any medium, provided the original work is properly cited.

Local inflammation is a prominent characteristic of snakebite wound, and snake-venom phospholipase $\mathrm{A}_{2} \mathrm{~s}\left(\mathrm{PLA}_{2} \mathrm{~s}\right)$ are some of the main component that contribute to accumulation of inflammatory cells. However, the action of an R49 PLA $\mathrm{A}_{2}$, promutoxin from Protobothrops mucrosquamatus venom, on mast-cell accumulation has not been previously examined. Using a mouse peritoneal model, we found that promutoxin can induce approximately-6-fold increase in mast-cell accumulation, and the response lasts at least for $16 \mathrm{~h}$. The promutoxin-induced mast cell accumulation was inhibited by cyproheptadine, terfenadine, and Ginkgolide B, indicating that histamine and platelet-activating factor (PAF) is likely to contribute to the mast-cells accumulation. Preinjection of antibodies against adhesion molecules ICAM-1, CD18, CD11a, and L-selectin showed that ICAM-1, and CD18, CD11a are key adhesion molecules of promutoxin-induced mast-cell accumulation. In conclusion, promutoxin can induce accumulation of mast cells, which may contribute to snake-venom wound.

\section{Introduction}

snake-venom phospholipase $\mathrm{A}_{2} \mathrm{~s}\left(\mathrm{PLA}_{2} \mathrm{~s}\right)$ are low-molecularweight $(13,000-14,000 \mathrm{Da})$, secretory phospholipases containing seven disulfide bonds. Usually, the $\mathrm{PLA}_{2} \mathrm{~s}$ from Crotalidae or Viperidae venom are divided into two major groups: the Asp-49 PLA $_{2}$ s (D49 PLA2s) and Lys-49 PLA 2 $\left(\mathrm{K}_{4} 9 \mathrm{PLA}_{2} \mathrm{~s}\right.$ ), and several minor groups: Ser-49 $\mathrm{PLA}_{2} \mathrm{~s}$ (S49 $\mathrm{PLA}_{2} \mathrm{~s}$ ) [1-3], Asn-49 $\mathrm{PLA}_{2} \mathrm{~s}$ (N49 PLA $\mathrm{PL}_{2}$ ) [4, 5], and Arg$49 \mathrm{PLA}_{2} \mathrm{~s}$ (R49 $\mathrm{PLA}_{2} \mathrm{~s}$ ) [6-8]. Besides the digestive function, snake $\mathrm{PLA}_{2} \mathrm{~s}$ exhibit several other pharmacological properties including antiplatelet $[9,10]$, anticoagulant [11], hemolytic [9], neurotoxic (presynaptic) [12], and myotoxic [13-15] properties. They have also been involved in various inflammatory processes such as edema, inflammatory cell infiltration, and mast-cell activation [15-20].

Mast cells are primarily located in mucosal and perivascular areas of various tissues, which play an important role in body-defense processes. Mast cells can be activated by snake-venom and release carboxypeptidase A and possibly other proteases, which can degrade venom components
$[21,22]$. Several snake-venom $\mathrm{PLA}_{2} \mathrm{~s}$ were reported to be able to activate the rat mast cells and to induce microvascular leakage and inflammatory-cell accumulation at the sites of inflammation [15-20]. Our previous studies showed that TM-N49, an N49 PLA 2 purified from Protobothrops mucrosquamatus venom, induces skin edema and mast-cell activation and accumulation [23], and promutoxin, an R49 $\mathrm{PLA}_{2}$ purified from the same snake, can activate mast cells and induce skin edema [24]. Both TM-N49 and promutoxin are devoid of catalytic activity and are thought to contribute to Protobothrops mucrosquamatus venom toxicity $[5,8]$. Moreover, both TM-N49 and promutoxin are potent stimuli for induction of neutrophil, lymphocyte, macrophage, and eosinophil accumulation in the mouse peritoneum [25]. These observations suggested that the two novel subgroups of group II PLA $\mathrm{P}_{2}$ may contribute to the inflammatory process caused by snake-venom poisoning. However, the ability of R49 PLA $_{2}$ on induction of mast-cell accumulation has not yet been reported. In the present study, we investigated the mechanisms of promutoxin-induced mast-cell accumulation. 


\section{Materials and Methods}

2.1. Reagents. Protobothrops mucrosquamatus crude venom was obtained from the stock of the Kunming Institute of Zoology, the Chinese Academy of Sciences. SPsephadex C-25, heparin sepharose (FF) and superdex 75 were obtained from LKB Pharmacia (Uppsala, Sweden). The following compounds were purchased from Sigma (St. Louis, USA): egg phosphatidyl choline, Triton X100 , trifluoroacetic acid, honey-bee venom phospholipase $\mathrm{A}_{2}$, platelet-activating factor (PAF), cyproheptadine, and ginkgolide B. Quinacrine was obtained from calbiochem (San Diego, CA, USA). Reagents for sodium dodecylsulphate-polyacrylamide gel electrophoresis (SDS-PAGE) were obtained from Bio-Rad Laboratories Inc. (Hercules, USA). Coomassie Plus assay kit was purchased from Pierce Chemical Co. (Rockford, IL, USA). Fetal-calf serum (FCS) and minimum essential medium (MEM) containing 25 mM N-2-hydroxyethylpiperazine- $N^{\prime}$-2-ethane sulphonic acid (HEPES) were purchased from Gibco (Paisley, Renfrewshire, UK). Rat monoclonal antibodies, anti-mouse CD 11a lymphocyte function-associated antigen 1 (LFA-1) $\alpha$ chain, clone M17/4; anti-mouse CD 62L (L-selectin), clone MEL-14; anti-mouse CD18 (integrin $\beta_{2}$ chain), clone M18/2; rat IgG2a isotype standard, clone R35-95; hamster antimouse CD54 intercellular adhesion molecule 1 (ICAM1) monoclonal antibody, clone $3 \mathrm{E} 2$; hamster $\operatorname{IgG} 1$ isotype standard, clone A19-3 were obtained from BD Biosciences Pharmigen (CA, USA). Hepes and all other chemicals were of analytical grade. BALB/c mice (20-25 g) were bred and reared under strict ethical conditions according to international recommendation.

2.2. Purification of Promutoxin. Promutoxin was isolated from Protobothrops mucrosquamatus crude venom following the procedures described previously [8]. Briefly, the lyophilized venom ( $1.5 \mathrm{~g}$ ) was dissolved in $20 \mathrm{~mL}$ of $0.05 \mathrm{M}$ sodium phosphate buffer ( $\mathrm{pH}$ 5.8) before being loaded on an SP-Sephadex C-25 column. The absorbed proteins were eluted with a linear gradient $(0-0.8 \mathrm{MNaCl})$. Peak 7 was collected and loaded on Superdex 75 column in $25 \mathrm{mM}$ sodium phosphate buffer ( $\mathrm{pH} 5.8$ with $0.15 \mathrm{M} \mathrm{NaCl}$ ). The main peak was collected, and then loaded on a reversephase $\mathrm{C}_{18}$ high-performance liquid chromatography (HPLC) (Waters Corporation, Milford, MA, USA). The main peak fraction, representing the purified promutoxin, was pooled, lyophilized, and stored at $-20^{\circ} \mathrm{C}$.

Protein concentration was determined by using a Coomassie Plus assay kit with BSA as standard. The $\mathrm{PLA}_{2}$ activity was routinely assayed by a titration method using egg yolk as substrate [26] and by a colorimetric assay using L-phosphatidylcholine as substrate [27]. Honey-bee PLA 2 was employed as positive control.

2.3. Induction of Mast-Cell Accumulation. Various doses of promutoxin, BSA or normal saline were injected in $0.5 \mathrm{~mL}$ volumes into the peritoneum of male $\mathrm{BALB} / \mathrm{c}$ mice, whose abdominal skin was swabbed with $70 \%$ ethanol, a group of 6 mice for each dose. This model was adapted from that described by Thomas and colleagues [28], which complied with the European Community guidelines for use of experimental animals. At $10 \mathrm{~min}, 2 \mathrm{~h}, 6 \mathrm{~h}$, or $16 \mathrm{~h}$ following injection, animals were sacrificed by inhalation of carbon dioxide, and their peritoneal lavages were collected following a standardized procedure with $5 \mathrm{~mL}$ normal saline. After centrifugation at $500 \mathrm{~g}$ for $10 \mathrm{~min}$ at $4^{\circ} \mathrm{C}$, supernatants were collected and stored at $-40^{\circ} \mathrm{C}$ until use, and cells were resuspended in $1 \mathrm{~mL}$ of MEM. The total cell numbers were determined by enumerating them with an Improved Neubauer haemocytometer after being stained with $0.1 \%$ trypan blue. For the differential cell counting, cytocentrifuge preparations were made, air dried, and stained with modified Wright's stain. Differential cell counts were performed for a minimum of 500 cells. The results were expressed as absolute numbers of each cell type per mouse peritoneum.

For the experiments investigating mast-cell-migration mechanisms, groups of mice were pretreated intravenously (tail vein injection) with monoclonal antibodies against the adhesion molecules L-selectin, CD11a, CD18, and ICAM1 (all at a dose of $1 \mathrm{mg} \cdot \mathrm{kg}^{-1}$ ) [29-31], respectively, for $30 \mathrm{~min}$ before intraperitoneal injection of $5 \mu \mathrm{g}$ of promutoxin. Control animals received an equivalent dose of the corresponding normal rat or hamster IgG isotype control. At $6 \mathrm{~h}$ following injection, the mice were sacrificed and their peritoneal lavages were processed as described above.

To investigate potential mechanisms involved in promutoxin-induced mast-cell accumulation, several anti-inflammatory compounds including cyproheptadine $\left(2 \mathrm{mg} \cdot \mathrm{kg}^{-1}\right)$ [17], terfenadine $\left(3 \mathrm{mg} \cdot \mathrm{kg}^{-1}\right)[32,33]$, ginkgolide $\mathrm{B}\left(5 \mathrm{mg} \cdot \mathrm{kg}^{-1}\right)$ [34], and quinacrine $\left(10 \mathrm{mg} \cdot \mathrm{kg}^{-1}\right)$ [35] were coinjected into the peritoneum of mice with promutoxin (5 $\mu \mathrm{g}$ per mouse). Control animals received an injection of drug alone. At $6 \mathrm{~h}$ following injection, mice were sacrificed and their peritoneal lavages were processed as described above.

2.4. Statistical Analysis. Data are shown as mean \pm SE for the number of experiments indicated, and ANOVA followed by Tukey's tests were used for statistical comparison of the data. In all analyses, $P<0.05$ was taken as statistically significant.

\section{Results}

3.1. Purification and Characterization of Promutoxin. Approximately $25 \mathrm{mg}$ of promutoxin was obtained from $1.5 \mathrm{~g}$ Protobothrops mucrosquamatus crude venom following the procedures described above. The purity of the $\mathrm{PLA}_{2}$ was at least $98 \%$ as assessed by SDS-PAGE, HPLC, and mass spectrometry analysis [24].

3.2. Induction of Mast-Cell Accumulation by Promutoxin. As early as $10 \mathrm{~min}$ following injection, $5 \mu \mathrm{g}$ of promutoxin was able to induce significant mast-cell accumulation in the peritoneum of mice. The mast-cell accumulation appeared to last for $16 \mathrm{~h}$ (Figure 1). Approximately, up to 6-fold increase 


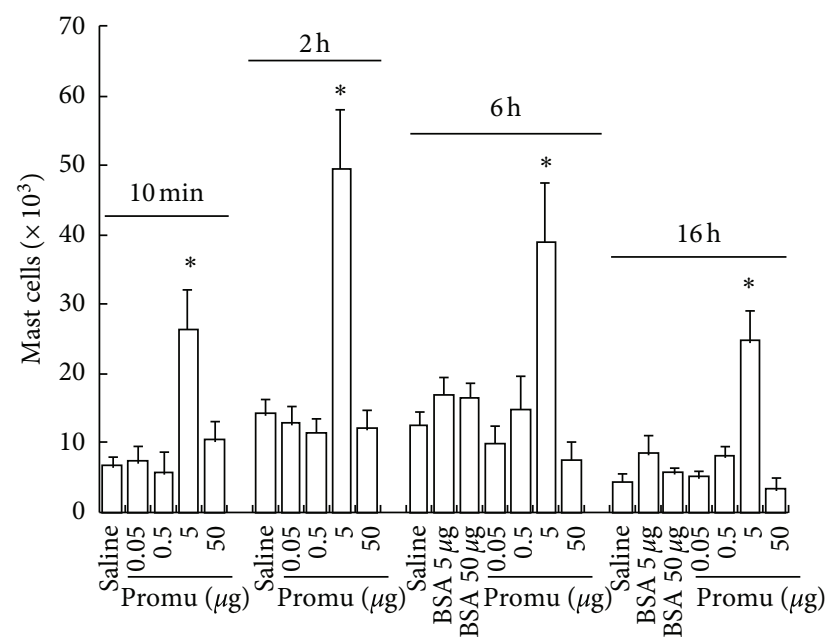

FigURE 1: Effect of promutoxin (promu) on mast-cell numbers in mouse peritoneum. Various doses of promu were injected into the peritoneum of mice for $10 \mathrm{~min}, 2 \mathrm{~h}, 6 \mathrm{~h}$, or $16 \mathrm{~h}$. Also shown are the responses to BSA and normal saline control. The values shown are mean \pm SE for 6 animals in each group. ${ }^{*} P<0.05$ compared with the response to the corresponding diluent-only control animals.

in mast-cell numbers was achieved at $16 \mathrm{~h}$ following injection (Figure 1).

3.3. Effects of Anti-Inflammatory Compounds and Blocking Antibodies on Mast-Cell Accumulation. When coinjected, ginkgolide B, cyproheptadine and terfenadine inhibited 35.9, 71.3 , and $92.6 \%$ promutoxin-induced mast-cell accumulation in the peritoneum of mice, respectively. However, quinacrine did not significantly alter the extent of promutoxin-induced mast-cell accumulation. At the dose tested, ginkgolide B, cyproheptadine, terfenadine, and quinacrine by themselves failed to induce mast-cell accumulation in the peritoneum of mice (Table 1).

Intravenous injection of monoclonal antibodies against CD18, ICAM-1, and CD11a 30 min prior to intraperitoneal injection of the $\mathrm{PLA}_{2}$-blocked promutoxin-induced mastcell accumulation by $87.2,76.7$, and $53.8 \%$, respectively. Monoclonal antibody against L-selectin failed to diminish promutoxin-induced mast-cell accumulation. Normal rat and hamster IgG-isotype controls tested had little effect on promutoxin-induced mast-cell accumulation (Table 2).

\section{Discussion}

It is found for the first time that promutoxin, a novel member of a minor subgroup (R49 $\mathrm{PLA}_{2}$ ) of snake-venom group II $\mathrm{PLA}_{2} \mathrm{~s}$, can induce mast-cell accumulation. The observation supports our previous finding that N49 PLA another minor subgroup of snake-venom group II PLA $\mathrm{PL}_{2}$ [23] can induce mast-cell accumulation. Obviously, promutoxin does not induce mast-cell accumulation in a concentrationdependent manner [24]. We previously found that promutoxin could activate mast-cells. The reduction of mast-cell
TABLE 1: The influence of anti-inflammatory compounds on promutoxin- $(5 \mu \mathrm{g})$ induced mast-cell accumulation in mouse peritoneum.

\begin{tabular}{lc}
\hline Compound injected & $\begin{array}{c}\text { Number of mast cells } \\
\left(\times 10^{3}\right)\end{array}$ \\
\hline Saline & $14.6(6.1-23)$ \\
Promutoxin & $44.6(21.4-60.8)$ \\
Ginkgolide B $5 \mathrm{mg} \cdot \mathrm{kg}^{-1}$ & $26.2(9.1-41)$ \\
Ginkgolide B $5 \mathrm{mg} \cdot \mathrm{kg}^{-1}+$ promutoxin & $28.6(13-50.2)^{*}$ \\
Cyproheptadine $2 \mathrm{mg} \cdot \mathrm{kg}^{-1}$ & $6.2(1.5-17.2)$ \\
Cyproheptadine $2 \mathrm{mg} \cdot \mathrm{kg}^{-1}+$ promutoxin & $12.8(4.2-22.2)^{*}$ \\
Terfenadine $2 \mathrm{mg} \cdot \mathrm{kg}^{-1}$ & $11.0(5.8-20)$ \\
Terfenadine $2 \mathrm{mg} \cdot \mathrm{kg}^{-1}+$ promutoxin & $3.3(1.6-6.5)^{*}$ \\
Quinacrine $10 \mathrm{mg} \cdot \mathrm{kg}^{-1}$ & $11.5(5.9-18.1)$ \\
Quinacrine $10 \mathrm{mg} \cdot \mathrm{kg}^{-1}+$ promutoxin & $36.8(25.3-49.3)$ \\
\hline
\end{tabular}

The values shown are medians (range) for six separate experiments. Compounds were injected into the mouse peritoneum for $6 \mathrm{~h}$ before peritoneal lavage fluid was collected. ${ }^{*} P<0.05$ compared with the response to promutoxin alone.

TABLE 2: The influence of blocking antibodies (Ab) against celladhesion molecules on promutoxin- $(5.0 \mu \mathrm{g})$ induced mast-cell accumulation in mouse peritoneum.

\begin{tabular}{lc}
\hline Compound injected & $\begin{array}{c}\text { Number of mast cells } \\
\left(\times 10^{3}\right)\end{array}$ \\
\hline Saline & $14.6(6.1-23)$ \\
Promutoxin & $44.6(21.4-60.8)$ \\
L-selectin Ab + promutoxin & $38.0(18.6-69.0)$ \\
LFA-1 Ab + promutoxin & $20.6(9.1-40)^{*}$ \\
CD18 Ab + promutoxin & $5.7(3.1-11.7)^{*}$ \\
ICAM-1 Ab + promutoxin & $10.4(2.9-14.5)^{*}$ \\
Hamster IgG1 + promutoxin & $39.8(17.0-63.1)$ \\
Rat IgG2a + promutoxin & $43.3(19.3-58.0)$ \\
\hline
\end{tabular}

The values shown are medians (range) for six separate experiments. Monoclonal antibodies (all at a dose of $1 \mathrm{mg} \cdot \mathrm{kg}^{-1}$ ) against the adhesion molecules L-selectin, LFA-1, CD18 and ICAM-1 were intravenously injected, respectively, for $30 \mathrm{~min}$ before intraperitoneal injection of $5 \mu \mathrm{g}$ promutoxin for $6 \mathrm{~h} .{ }^{*} \mathrm{P}<0.05$ compared with the response to promutoxin alone.

number induced by promutoxin in higher doses may be due to the activation of accumulated mast-cells by promutoxin.

Ginkgolide B, a PAF antagonist, inhibited more than $35.9 \%$ promutoxin-induced mast-cell migration, indicating that PAF is likely involved in mast-cell migration by promutoxin. This result appears to agree with a previous work which found that PAF may contribute to mast-cell migration induced by TM-N49 [23]. Inhibition of 71.3 and $92.6 \%$ promutoxin-induced mast-cell accumulation by cyproheptadine, a histamine/5-HT antagonist, and terfenadine a selective histamine- $\mathrm{H}_{1}$-receptor antagonist, implies that histamine is likely to be involved in the above event through its $\mathrm{H}_{1}$ receptor. Indeed, we have found previously that promutoxin can activate mast cells to release histamine [24] and anticipate herein that released histamine then elicits mast-cell migration. The fact that terfenadine inhibited 
promutoxin-provoked mast-cell recruitment to a greater extent than cyproheptadine further implies the selectivity of histamine receptor involved. It was found that snake-venom promutoxin could induce mast-cell accumulation even at 10 min following injection, but the number of lymphocyte, macrophage, eosinophil, and neutrophil migration was not altered at $10 \mathrm{~min}$ following injection of promutoxin [25]. It seemed the accumulation of neutrophils, lymphocyte, macrophage, and eosinophil induced by promutoxin could be a secondary event, in which accumulated mast cells are activated by promutoxin and release their chemoattractant factors such as serine proteinases $[36,37]$, histamine, and PAF to recruit inflammatory cells.

ICAM-1 appears to be a key adhesion molecule of promutoxin-induced mast-cell accumulation as an antibody against ICAM-1 blocked more than $76.7 \%$ of the influence of promutoxin on the cell migration. ICAM-1 involved in lymphocyte [38], macrophage [39], eosinophil [40, 41] and mast-cell accumulation [23] has been reported previously, which may support our current observations. An antibody against CD11a (LFA-1) blocked more than $53.8 \%$ promutoxin-induced mast-cell accumulation, indicating that CD11a plays an important role in the migration of mast cells, which is consistent with previous reports that TMN49-induced mast-cell accumulation is mediated by CD18, CD11a, and ICAM-1 [23]. As expected, antibody against CD18 blocked more than $87.2 \%$ promutoxin-induced mastcell accumulation in the present study. Though L-selectin is involved in the neutrophil and eosinophil accumulation provoked by promutoxin, it seemed that L-selectin is not involved in the promutoxin-induced mast-cell accumulation.

Promutoxin, as a novel member of minor subgroup of $\mathrm{PLA}_{2}$, is an enzymatically inactive enzyme. It induced mastcell accumulation via a PAF, and histamine $\mathrm{H}_{1}$ receptordependent mechanism, and through a CD11a/CD18-and ICAM-1-associated adhesion pathway. Accumulated mast cells may contribute to snake-venom wound.

\section{Acknowledgments}

The authors are grateful to Miss Jie-lian Lin and Miss Qiu$\mathrm{Yu}$ Chen for their assistance in the animal experiments. This paper was sponsored by the Grants from the National Natural Science Foundation of China (30972822, 81273274, 81001329, and 30972714), Jiangsu Province's Key Provincial Talents Program (RC201170), the Key Allergy Laboratory Fund of Jiangsu Province, China (XK201115), and a project funded by the Priority Academic Program Development of Jiangsu Higher Education Institutions (PAPD).

\section{References}

[1] J. Polgár, E. M. Magnenat, M. C. Peitsch, T. N. C. Wells, and K. J. Clemetson, "Asp-49 is not an absolute prerequisite for the enzymic activity of low- $M_{\mathrm{r}}$ phospholipases $\mathrm{A}_{2}$ : purification, characterization and computer modelling of an enzymically active Ser-49 phospholipase $A_{2}$, ecarpholin $S$, from the venom of Echis carinatus sochureki (saw-scaled viper)," Biochemical Journal, vol. 319, no. 3, pp. 961-968, 1996.
[2] I. Krizaj, A. L. Bieber, A. Ritonja, and F. Gubensek, “The primary structure of ammodytin $\mathrm{L}$, a myotoxic phospholipase $\mathrm{A}_{2}$ homologue from Vipera ammodytes venom," European Journal of Biochemistry, vol. 202, no. 3, pp. 1165-1168, 1991.

[3] X. Zhou, T. C. Tan, S. Valiyaveettil et al., "Structural characterization of myotoxic ecarpholin S from Echis carinatus venom," Biophysical Journal, vol. 95, no. 7, pp. 3366-3380, 2008.

[4] I. H. Tsai, Y. M. Wang, Y. H. Chen, T. S. Tsai, and M. C. $\mathrm{Tu}$, "Venom phospholipases $\mathrm{A}_{2}$ of bamboo viper (Trimeresurus stejnegeri): molecular characterization, geographic variations and evidence of multiple ancestries," Biochemical Journal, vol. 377, no. 1, pp. 215-223, 2004.

[5] J. F. Wei, X. L. Wei, Q. Y. Chen et al., "N49 phospholipase $A_{2}$, a unique subgroup of snake venom group II phospholipase $\mathrm{A}_{2}$," Biochimica et Biophysica Acta, vol. 1760, no. 3, pp. 462-471, 2006.

[6] T. Chijiwa, E. Tokunaga, R. Ikeda et al., "Discovery of novel [Arg ${ }^{49}$ ]phospholipase $\mathrm{A}_{2}$ isozymes from Protobothrops elegans venom and regional evolution of Crotalinae snake venom phospholipase $\mathrm{A}_{2}$ isozymes in the Southwestern islands of Japan and Taiwan," Toxicon, vol. 48, no. 6, pp. 672-682, 2006.

[7] D. Mebs, U. Kuch, F. I. V. Coronas, C. V. F. Batista, A. Gumprecht, and L. D. Possani, "Biochemical and biological activities of the venom of the Chinese pitviper Zhaoermia mangshanensis, with the complete amino acid sequence and phylogenetic analysis of a novel Arg49 phospholipase $\mathrm{A}_{2}$ myotoxin," Toxicon, vol. 47, no. 7, pp. 797-811, 2006.

[8] J. F. Wei, T. Li, X. L. Wei et al., "Purification, characterization and cytokine release function of a novel Arg- 49 phospholipase $A_{2}$ from the venom of Protobothrops mucrosquamatus," Biochimie, vol. 88, no. 10, pp. 1331-1342, 2006.

[9] Q. M. Lu, Y. Jin, J. F. Wei et al., "Characterization and cloning of a novel phospholipase $\mathrm{A}_{2}$ from the venom of Trimeresurus jerdonii snake," Toxicon, vol. 40, no. 9, pp. 1313-1319, 2002.

[10] Q. M. Lu, Y. Jin, J. F. Wei, W. Y. Wang, and Y. L. Xiong, "Biochemical and biological properties of Trimeresurus jerdonii venom and characterization of a platelet aggregation-inhibiting acidic phospholipase $\mathrm{A}_{2}$," Journal of Natural Toxins, vol. 11, no. 1, pp. 25-33, 2002.

[11] R. M. Kini, "Structure-function relationships and mechanism of anticoagulant phospholipase $\mathrm{A}_{2}$ enzymes from snake venoms," Toxicon, vol. 45, no. 8, pp. 1147-1161, 2005.

[12] I. H. Tsai, P. J. Lu, Y. M. Wang, C. L. Ho, and L. L. Liaw, "Molecular cloning and characterization of a neurotoxic phospholipase $\mathrm{A}_{2}$ from the venom of Taiwan habu (Trimeresurus mucrosquamatus)," Biochemical Journal, vol. 311, no. 3, pp. 895-900, 1995.

[13] A. M. Soares, R. Guerra-Sá, C. R. Borja-Oliveira et al., "Structural and functional characterization of BnSP-7, a Lys49 myotoxic phospholipase $\mathrm{A}_{2}$ homologue from Bothrops neuwiedi pauloensis venom," Archives of Biochemistry and Biophysics, vol. 378, no. 2, pp. 201-209, 2000.

[14] A. M. Soares, S. H. Andrião-Escarso, Y. Angulo et al., "Structural and functional characterization of myotoxin I, a Lys49 phospholipase $\mathrm{A}_{2}$ homologue from Bothrops moojeni (Caissaca) snake venom," Archives of Biochemistry and Biophysics, vol. 373 , no. 1, pp. 7-15, 2000.

[15] M. M. Kanashiro, R. de Cássia M Escocard, J. H. Petretski et al., "Biochemical and biological properties of phospholipases $\mathrm{A}_{2}$ from Bothrops atrox snake venom," Biochemical Pharmacology, vol. 64, no. 7, pp. 1179-1186, 2002. 
[16] S. Lloret and J. J. Moreno, "Oedema formation and degranulation of mast cells by phospholipase $\mathrm{A}_{2}$ purified from porcine pancreas and snake venoms," Toxicon, vol. 31, no. 8, pp. 949-956, 1993.

[17] E. C. T. Landucci, R. C. de Castro, M. Toyama et al., "Inflammatory oedema induced by the Lys- 49 phospholipase $\mathrm{A}_{2}$ homologue piratoxin-i in the rat and rabbit: effect of polyanions and p-bromophenacyl bromide," Biochemical Pharmacology, vol. 59, no. 10, pp. 1289-1294, 2000.

[18] C. F. P. Teixeira, E. C. T. Landucci, E. Antunes, M. Chacur, and Y. Cury, "Inflammatory effects of snake venom myotoxic phospholipases $A_{2}$," Toxicon, vol. 42, no. 8, pp. 947-962, 2003.

[19] J. P. Zuliani, J. M. Gutiérrez, L. L. Casais e Silva, S. C. Sampaio, B. Lomonte, and C. D. F. Pereira Teixeira, "Activation of cellular functions in macrophages by venom secretory Asp-49 and Lys49 phospholipases $\mathrm{A}_{2}$," Toxicon, vol. 46, no. 5, pp. 523-532, 2005.

[20] E. C. T. Landucci, R. C. Castro, M. F. Pereira et al., "Mast cell degranulation induced by two phospholipase $\mathrm{A}_{2}$ homologues: dissociation between enzymatic and biological activities," European Journal of Pharmacology, vol. 343, no. 2-3, pp. 257-263, 1998.

[21] M. Metz, A. M. Piliponsky, C. C. Chan et al., "Mast cells can enhance resistance to snake and honeybee venoms," Science, vol. 313, no. 5786, pp. 526-530, 2006.

[22] L. A. Schneider, S. M. Schlenner, T. B. Feyerabend, M. Wunderlin, and H. R. Rodewald, "Molecular mechanism of mast cellmediated innate defense against endothelin and snake venom sarafotoxin," Journal of Experimental Medicine, vol. 204, no. 11, pp. 2629-2639, 2007.

[23] J. F. Wei, X. L. Wei, Y. Z. Mo, and S. H. He, "Induction of mast cell accumulation, histamine release and skin edema by $\mathrm{N} 49$ phospholipase $\mathrm{A}_{2}$," BMC Immunology, vol. 10, article 21, 2009.

[24] J. F. Wei, X. L. Wei, Y. Z. Mo, and S. H. He, "Induction of microvascular leakage and histamine release by promutoxin, an Arg49 phospholipase $A_{2}$," Toxicon, vol. 55, no. 4, pp. 888-896, 2010.

[25] J. F. Wei, X. L. Wei, Q. Y. Chen, and S. H. He, "Induction of inflammatory cell accumulation by TM-N49 and promutoxin, two novel phospholipase $\mathrm{A}_{2}$," Toxicon, vol. 56, no. 4, pp. 580-588, 2010.

[26] K. Ishimaru, H. Kihara, and M. Ohno, "Purification and properties of phospholipase $\mathrm{A}_{2}$ from venom of Trimeresurus flavoviridis (Habu snake)," Journal of Biochemistry, vol. 88, no. 2, pp. 443-451, 1980.

[27] A. L. de Araújo and F. Radvanyi, "Determination of phospholipase $\mathrm{A}_{2}$ activity by a colorimetric assay using a $\mathrm{pH}$ indicator," Toxicon, vol. 25, no. 11, pp. 1181-1188, 1987.

[28] C. A. Thomas, F. J. Yost Jr., R. Snyderman et al., "Cellular serine proteinase induces chemotaxis by complement activation," Nature, vol. 269, no. 5628, pp. 521-522, 1977.

[29] C. M. Fernandes, S. R. Zamuner, J. P. Zuliani, A. Rucavado, J. M. Gutiérrez, and C. F. Teixeira, "Inflammatory effects of BaP1 a metalloproteinase isolated from Bothrops asper snake venom: leukocyte recruitment and release of cytokines," Toxicon, vol. 47, no. 5, pp. 549-559, 2006.

[30] S. R. Zamuner, J. P. Zuliani, C. M. Fernandes, J. M. Gutiérrez, and C. F. Teixeira, "Inflammation induced by Bothrops asper venom: release of proinflammatory cytokines and eicosanoids, and role of adhesion molecules in leukocyte infiltration," Toxicon, vol. 46, no. 7, pp. 806-813, 2005.
[31] J. P. Zuliani, C. M. Fernandes, S. R. Zamuner, J. M. Gutiérrez, and C. F. Teixeira, "Inflammatory events induced by Lys-49 and Asp-49 phospholipases $\mathrm{A}_{2}$ isolated from Bothrops asper snake venom: role of catalytic activity," Toxicon, vol. 45, no. 3, pp. 335-346, 2005.

[32] A. Takahara, A. Sugiyama, Y. Satoh, and K. Hashimoto, "Comparison of four rate-correction algorisms for the ventricular repolarization period in assessing net effects of IKr blockers in dogs," Journal of Pharmacological Sciences, vol. 102, no. 4, pp. 396-404, 2006.

[33] A. Takahara, A. Sugiyama, and K. Hashimoto, "Reduction of repolarization reserve by halothane anaesthesia sensitizes the guinea-pig heart for drug-induced QT interval prolongation,” British Journal of Pharmacology, vol. 146, no. 4, pp. 561-567, 2005.

[34] I. A. Desouza and G. Ribeiro-DaSilva, "The pharmacological profile of mouse hind paw inflammation induced by staphylococcal enterotoxin type A," Inflammation Research, vol. 46, no. 9, pp. 361-365, 1997.

[35] B. G. Southorn and R. M. Palmer, "Inhibitors of phospholipase $\mathrm{A}_{2}$ block the stimulation of protein synthesis by insulin in L6 myoblasts," Biochemical Journal, vol. 270, no. 3, pp. 737-739, 1990.

[36] S. He, M. D. A. Gaça, and A. F. Walls, "A role for tryptase in the activation of human mast cells: modulation of histamine release by tryptase and inhibitors of tryptase," Journal of Pharmacology and Experimental Therapeutics, vol. 286, no. 1, pp. 289-297, 1998.

[37] S. He, M. D. A. Gaça, A. R. McEuen, and A. F. Walls, "Inhibitors of chymase as mast cell-stabilizing agents: contribution of chymase in the activation of human mast cells," Journal of Pharmacology and Experimental Therapeutics, vol. 291, no. 2, pp. 517-523, 1999.

[38] G. Lisignoli, S. Toneguzzi, A. Piacentini et al., "Recruitment and proliferation of T lymphocytes is supported by IFN $\gamma$ and TNF $\alpha$-activated human osteoblasts: involvement of CD54 (ICAM-1) and CD106 (VCAM-1) adhesion molecules and CXCR3 chemokine receptor," Journal of Cellular Physiology, vol. 198, no. 3, pp. 388-398, 2004.

[39] C. Duplàa, T. Couffinhal, L. Labat et al., "Monocyte/macrophage recruitment and expression of endothelial adhesion proteins in human atherosclerotic lesions," Atherosclerosis, vol. 121, no. 2, pp. 253-266, 1996.

[40] M. Ebisawa, B. S. Bochner, S. N. Georas, and R. P. Schleimer, "Eosinophil transendothelial migration induced by cytokines. I. Role of endothelial and eosinophil adhesion molecules in IL- $1 \beta$-induced transendothelial migration," The Journal of Immunology, vol. 149, no. 12, pp. 4021-4028, 1992.

[41] E. Forbes, M. Hulet, R. Ahrens et al., "ICAM-1-dependent pathways regulate colonic eosinophilic inflammation," Journal of Leukocyte Biology, vol. 80, no. 2, pp. 330-341, 2006. 

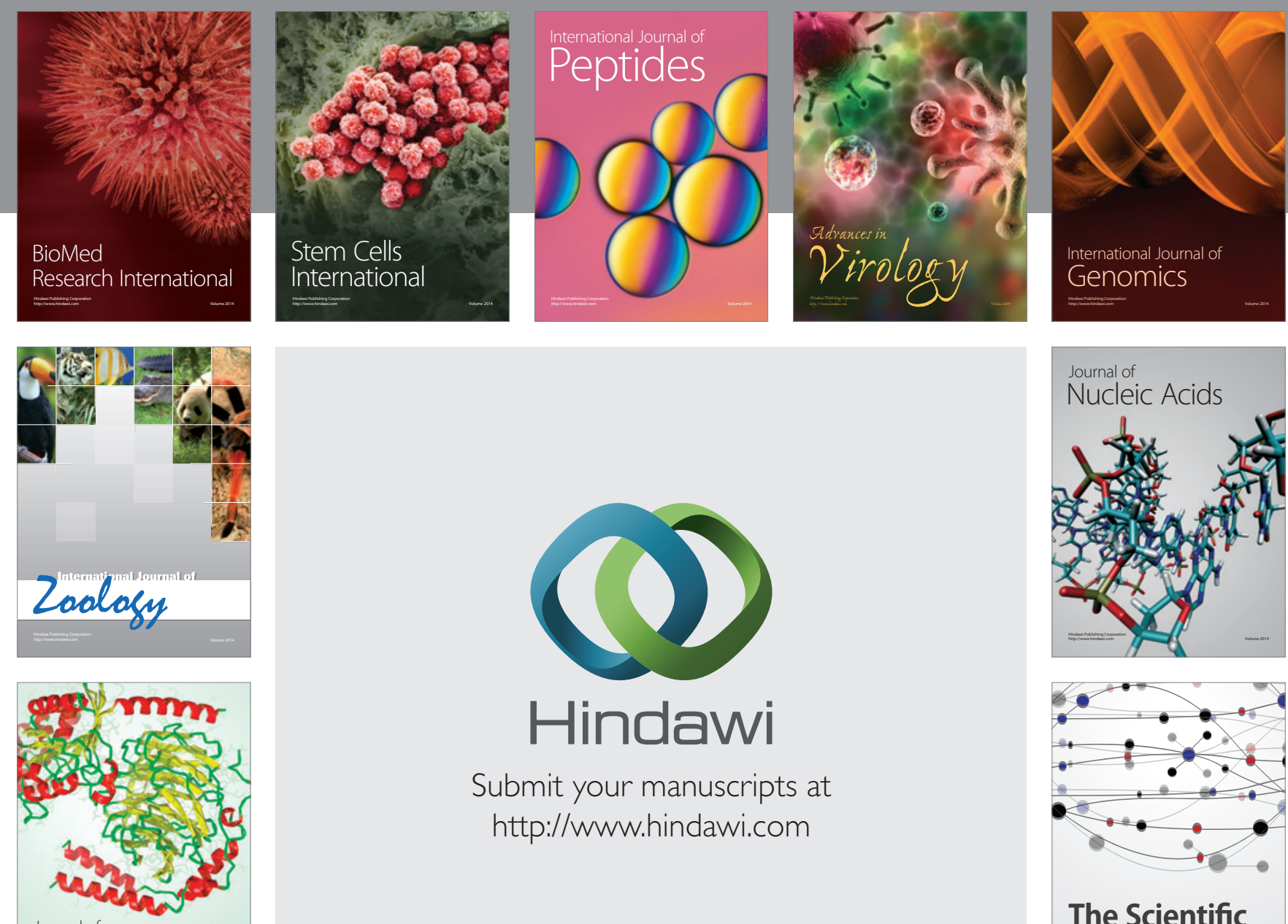

Submit your manuscripts at

http://www.hindawi.com

Journal of
Signal Transduction
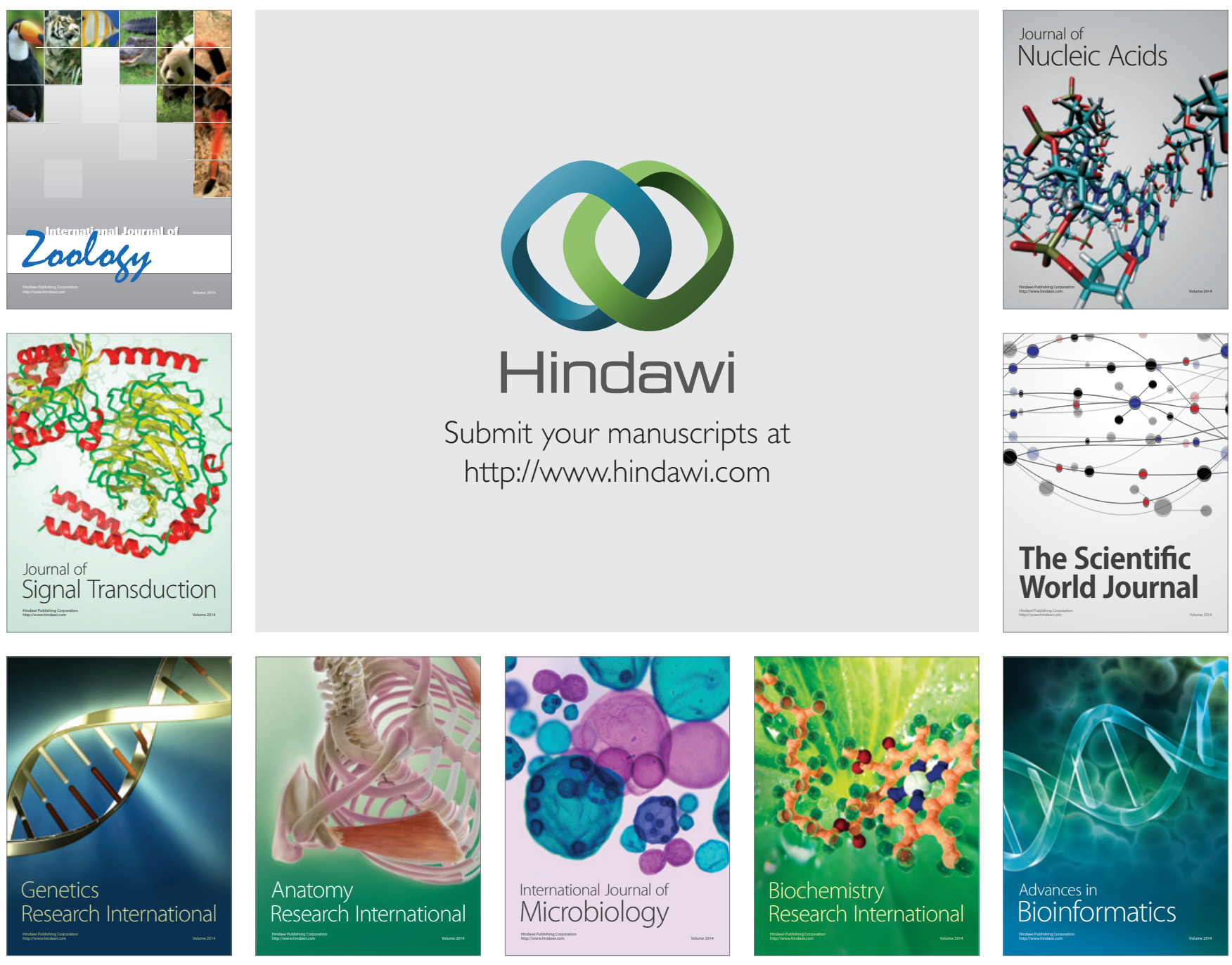

The Scientific World Journal
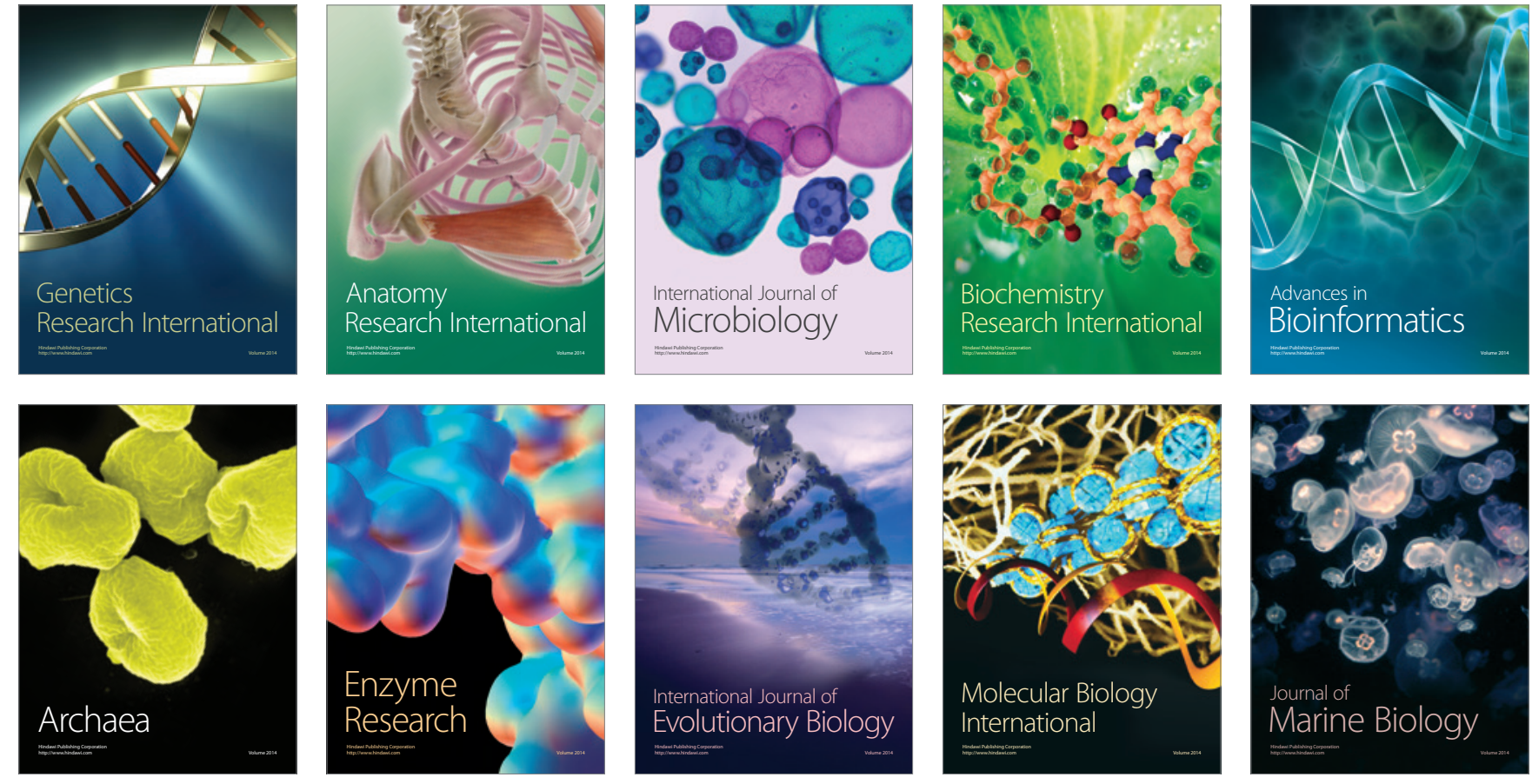